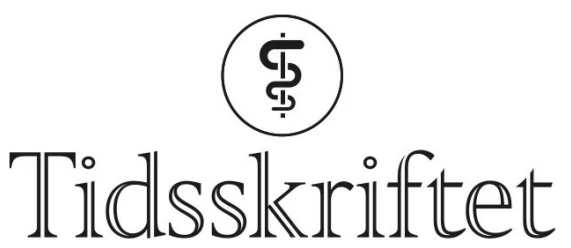

DEN NORSKE LEGEFORENING

\title{
Tiårsprediksjon av hjerte- og karsykdom hos friske norske menn basert på NORRISK-2
}

ORIGINALARTIKKEL

\section{YUSUF MIRZA}

Det medisinske fakultet

Universitetet i Oslo

Han har bidratt med dataanalyse, tolkning av data og utarbeiding, revisjon og godkjenning av manus. Yusuf Mirza er cand.med.

Forfatteren har fylt ut ICMJE-skjemaet og oppgir ingen interessekonflikter.

\section{ERIK E. PRESTGAARD}

Sykehuset i Vestfold, Tønsberg

Han har bidratt med design, dataanalyse, tolkning av data og utarbeiding, revisjon og godkjenning av manus.

Erik E. Prestgaard er LIS2-lege.

Forfatteren har fylt ut ICMJE-skjemaet og oppgir ingen interessekonflikter.

\section{RANDI SELMER}

Folkehelseinstituttet

Hun har bidratt med dataanalyse, tolkning av data og utarbeiding, revisjon og godkjenning av manus.

Randi Selmer er dr.philos. og seniorforsker.

Forfatteren har fylt ut ICMJE-skjemaet og oppgir ingen interessekonflikter.

\section{KNUT LIEST ØL}

Institutt for informatikk

Universitetet i Oslo

Han har bidratt med dataanalyse, tolkning av data og utarbeiding, revisjon og godkjenning av manus. Knut Liestøl er dr.philos. og professor.

Forfatteren har fylt ut ICMJE-skjemaet og oppgir ingen interessekonflikter.

\section{IRENE GRUNDVOLD}

Hjertemedisinsk avdeling Oslo universitetssykehus, Ullevål og Avdeling for hjertesykdommer Akershus universitetssykehus Hun har bidratt med tolkning av data og utarbeiding, revisjon og godkjenning av manus. Irene Grundvold er ph.d. og seksjonsoverlege. 


\section{JAN E. ERIKSSEN}

Institutt for klinisk medisin

Universitetet i Oslo

Han har bidratt med idé, tolkning av data og utarbeiding, revisjon og godkjenning av manus.

Jan E. Erikssen er dr.med. og professor emeritus.

Forfatteren har fylt ut ICMJE-skjemaet og oppgir ingen interessekonflikter.

\section{SVERRE E. KJELDSEN}

Institutt for klinisk medisin

Universitetet i Oslo

og

Hjertemedisinsk avdeling

Oslo universitetssykehus, Ullevål

Han har bidratt med idé, design, tolkning av data og utarbeiding, revisjon og godkjenning av manus.

Sverre E. Kjeldsen er dr.med., seksjonsoverlege og professor.

Forfatteren har fylt ut ICMJE-skjemaet og oppgir ingen interessekonflikter.

\section{KNUT GJESDAL}

knut.gjesdal@medisin.uio.no

Institutt for klinisk medisin

Universitetet i Oslo

og

Hjertemedisinsk avdeling

Oslo universitetssykehus, Ullevål

Han har bidratt med idé, design, tolkning av data og utarbeiding, revisjon og godkjenning av manus.

Knut Gjesdal er dr.med. og professor emeritus.

Forfatteren har fylt ut ICMJE-skjemaet og oppgir ingen interessekonflikter.

\section{BAKGRUNN}

Norske retningslinjer for primærforebygging av hjerte- og karsykdom anbefaler bruk av risikoskårmodellen NORRISK-2, med noen tillegg. Vi ønsket å undersøke om NORRISK-2 kunne predikere hjerte- og karsykdom hos friske norske menn som deltok i kohortstudien Oslo Ischemia Study.

MATERIALE

NORRISK-2-skår ble beregnet for 2014 menn i aldersgruppen 40-6o år som i 1972-75 ble inkludert i Oslo Ischemia Study. Cox-regresjonsanalyser ble benyttet for å kalkulere hasardratio for død og hjerte- og karsykdom innen ti år etter førstegangsundersøkelsen.

RESULTATER

Ingen gikk tapt fra oppfølgingen. Av de 2014 mennene døde 125 i første tiår etter inklusjon, hvorav 61 av kardiovaskulær sykdom. De som døde, var eldre enn de overlevende, med større andel dagligrøykere, og de hadde høyere systolisk blodtrykk og hvilepuls, økt totalkolesterol og lavere fysisk yteevne. Majoriteten av de som døde av akutt hjerteinfarkt og hjerneslag innen ti år, ble i NORRISK-2 klassifisert i høyrisikogruppen.

\section{FORTOLKNING}

NORRISK-2 identifiserte høyrisikopersonene godt i denne kohorten av friske, middelaldrende norske menn. Det støtter bruk av de norske retningslinjene i beslutningen om eventuell primærforebygging av hjerte- og karsykdom. 
NORRISK-2, et enkelt skåringssystem for tiårsrisiko for hjerte- og karsykdom, identifiserte de fleste som utviklet hjerte- og karsykdom innen ti år blant 2014 friske menn i alderen 4060 år som ble undersøkt i 1970-årene.

Utover faktorene i NORRISK-2 (alder, kjønn, dagligrøyking, s-kolesterol, systolisk blodtrykk) var fysisk yteevne under median en robust risikofaktor for sykdom.

I den norske befolkningen har $21 \%$ etablert hjerte- og karsykdom eller økt risiko for å få det (1), og i dag bruker omtrent 1,1 millioner nordmenn legemidler for å forebygge slik sykdom (1). Vi har en rekke forebyggende muligheter, så utfordringen er å finne dem som best trenger tiltak. Ved siden av upåvirkelige risikofaktorer som arv, alder og kjønn, er de viktigste risikofaktorene hypertensjon, røyking, forhøyet kolesterolverdi og lite fysisk aktivitet. Det er utviklet gode algoritmer for å identifisere høyrisikoindivider, senest av Rossello og medarbeidere (2). Best kjent i Norge er NORRISK, som i 2017 ble revidert til NORRISK-2. Modellen er basert på flere norske kohortstudier og registerdata, og anslår risikoen for dødelig og ikke-dødelig koronarsykdom og hjerneslag i løpet av de neste ti år (3).

Oslo Ischemia Study (OIS) er en kohortstudie av 2014 middelaldrende menn som var friske ved inklusjonen i 1972-75, og som er fulgt opp i 35 år. Hovedhensikten var å unders $ø$ ke forekomsten av uoppdaget koronarsykdom hos antatt friske menn, og dernest å relatere funn ved basisundersøkelsen til utvikling av kardiovaskulær sykdom senere (4.). Et bredt panel av kliniske opplysninger, blodprøver, røntgenbilder og funksjonsmålinger ble gjort ved inklusjonen. Til tross for at deltakerne ble bedømt som friske, døde mange i løpet av de første ti observasjonsårene.

Vi ønsket å validere NORRISK-2 i en uavhengig norsk kohortstudie ved å undersøke hvor mange av de tidlig syke eller døde i Oslo Ischemia Study som etter dagens retningslinjer ville ha blitt anbefalt primærprofylaktisk behandling mot hjerte- og karsykdom. I tillegg ville vi undersøke om risikovurderingen kunne forbedres ved å inkludere et mål for fysisk yteevne, noe som ikke inngår i NORRISK-2-modellen.

\section{Materiale og metode}

\section{OSLO ISCHEMIA STUDY}

Bedriftslegene ved fem store arbeidsplasser i Oslo henviste antatt friske menn (40-59 år) til studien, og 2014 ( $86 \%$ av de forespurte) deltok. Den første undersøkelsen fant sted i årene 1972-75 og omfattet sykehistorie, klinisk undersøkelse og blodprøver. Også hjerte- og lungefunksjon ble testet, og fysisk yteevne ble kartlagt med ergometersykling med 50 watt $\varnothing \mathrm{kt}$ belastning hvert sjette minutt inntil nær utmattelse. Morbiditets- og mortalitetsdata er komplette til og med 31.12.2007, fra henholdsvis siste oppfølging (5) og Statistisk sentralbyrå. Kombinert hjerte- og karmorbiditet og -mortalitet er primært endepunkt. Kardiovaskulær død er definert som død av hjerteinfarkt, akutt hjertedød, hjerneslag, lungeembolisme eller aortasykdom. Koronarsykdom er definert som angina pectoris eller ikke-fatalt hjerteinfarkt.

NORRISK-2

Modellpopulasjonen for NORRISK er 66712 menn og kvinner i alderen 40-79 år fra undersøkelsen Cohort of Norway (CONOR) i 1994-99, og valideringspopulasjonen 39289 deltakere i CONOR i 2000-03, begge uten selvrapportert hjerte- og karsykdom eller sykehusopphold med slik diagnose (므). Endepunkter kom fra prosjektet Cardiovascular Disease in Norway (CVDNOR) (7.). For perioden 1994-2009 ble alle sykehusinnleggelser, dødsårsaker og dødsdatoer innhentet. Første hendelse var endepunkt: Innleggelse for akutt hjerteinfarkt eller hjerneslag samt død av koronarsykdom eller hjerneslag. Død av 
andre årsaker ble behandlet som konkurrerende risiko. I modellpopulasjonen ble det 6117 endepunkter innen ti år (3); i valideringspopulasjonen 2 732. NORRISK-2 gir samlet risiko for sykdom og død innen ti år (3). Man legger inn alder, kjønn, s-totalkolesterol, systolisk blodtrykk og dagligrøyking i diagrammet, og fargekodene følger grensene for høy risiko ut fra våre nasjonale retningslinjer (figur 1) (ㅁ). I modellen inngår også familiehistorikk på hjerte- og karsykdom, pågående hypertensjonsbehandling og s-HDL-kolesterol (3); se risikokalkulator hos Helsedirektoratet (9.).

\begin{tabular}{|c|c|c|c|c|c|c|c|c|c|c|c|}
\hline \multirow[t]{2}{*}{ Alder $(\stackrel{a}{\mathrm{a}} \mathrm{r})$} & \multicolumn{2}{|l|}{ Systolisk blodtrykk ( $\mathrm{mm} \mathrm{Hg}$ ) } & \multicolumn{4}{|c|}{ Ikke-røyker } & \multicolumn{5}{|c|}{ Røyker } \\
\hline & 160 & 17 & 18 & 19 & 20 & 22 & 21 & 23 & 24 & 25 & 27 \\
\hline & 150 & 16 & 17 & 18 & 19 & 20 & 20 & 21 & 22 & 24 & 25 \\
\hline \multirow[t]{5}{*}{$70-74$} & 140 & 15 & 15 & 16 & 17 & 19 & 18 & 20 & 21 & 22 & 23 \\
\hline & 130 & 13 & 14 & 15 & 16 & 17 & 17 & 18 & 19 & 20 & 22 \\
\hline & 120 & 12 & 13 & 14 & 15 & 16 & 16 & 17 & 18 & 19 & 20 \\
\hline & 160 & 12 & 13 & 15 & 17 & 18 & 17 & 19 & 21 & 23 & 25 \\
\hline & 150 & 11 & 12 & 14 & 15 & 17 & 15 & 17 & 19 & 21 & 23 \\
\hline \multirow[t]{5}{*}{$65-69$} & 140 & 10 & 11 & 12 & 14 & 15 & 14 & 15 & 17 & 19 & 21 \\
\hline & 130 & 9 & 10 & 11 & 12 & 14 & 13 & 14 & 15 & 17 & 19 \\
\hline & 120 & 8 & 9 & 10 & 11 & 12 & 11 & 13 & 14 & 16 & 17 \\
\hline & 160 & 8 & 10 & 11 & 13 & 15 & 13 & 15 & 17 & 20 & 23 \\
\hline & 150 & 7 & 9 & 10 & 12 & 13 & 12 & 13 & 16 & 18 & 21 \\
\hline \multirow[t]{5}{*}{$60-64$} & 140 & 6 & 8 & 9 & 10 & 12 & 10 & 12 & 14 & 16 & 18 \\
\hline & 130 & 6 & 7 & 8 & 9 & 11 & 9 & 10 & 12 & 14 & 16 \\
\hline & 120 & 5 & 6 & 7 & 8 & 9 & 8 & 9 & 11 & 13 & 15 \\
\hline & 160 & 5 & 7 & 8 & 10 & 12 & 10 & 12 & 14 & 17 & 21 \\
\hline & 150 & 5 & 6 & 7 & 9 & 11 & 8 & 10 & 12 & 15 & 18 \\
\hline \multirow[t]{5}{*}{ 55-59 } & 140 & 4 & 5 & 6 & 8 & 9 & 7 & 9 & 11 & 13 & 16 \\
\hline & 130 & 3 & 4 & 5 & 6 & 8 & 6 & 8 & 9 & 11 & 14 \\
\hline & 120 & 3 & 4 & 4 & 6 & 7 & 5 & 7 & 8 & 10 & 12 \\
\hline & 160 & 3 & 5 & 6 & 8 & 10 & 7 & 9 & 11 & 15 & 18 \\
\hline & 150 & 3 & 4 & 5 & 6 & 8 & 6 & 8 & 10 & 12 & 16 \\
\hline \multirow[t]{5}{*}{$50-54$} & 140 & 2 & 3 & 4 & 5 & 7 & 5 & 6 & 8 & 10 & 13 \\
\hline & 130 & 2 & 3 & 3 & 4 & 6 & 4 & 5 & 7 & 9 & 11 \\
\hline & 120 & 2 & 2 & 3 & 4 & 5 & 3 & 4 & 6 & 7 & 10 \\
\hline & 160 & 2 & 3 & 4 & 5 & 7 & 5 & 7 & 9 & 12 & 16 \\
\hline & 150 & 2 & 2 & 3 & 4 & 6 & 4 & 5 & 7 & 10 & 13 \\
\hline \multirow[t]{4}{*}{$45-49$} & 140 & 1 & 2 & 3 & 4 & 5 & 3 & 4 & 6 & 8 & 11 \\
\hline & 130 & 1 & 1 & 2 & 3 & 4 & 3 & 4 & 5 & 7 & 9 \\
\hline & 120 & 1 & 1 & 2 & 2 & 3 & 2 & 3 & 4 & 5 & 7 \\
\hline & & 4 & 5 & 6 & 7 & 8 & 4 & 5 & 6 & 7 & 8 \\
\hline
\end{tabular}

Aldersspesifikke tiårsrisikokategorier(\%)

\begin{tabular}{|c|c|c|c|}
\hline Alder(år) & Lav risiko & Middels risiko & Høy risiko \\
\hline $65-74$ & $<12,0$ & $12,0-14,9$ & $\geq 15,0$ \\
\hline $55-64$ & $<8,0$ & $8,0-9,9$ & $\geq 10,0$ \\
\hline $45-54$ & $<4,0$ & $4,0-4,9$ & $\geq 5,0$ \\
\hline
\end{tabular}

Figur 1 NORRISK-2-fargediagram viser tiårsrisiko for dødelig og ikke-dødelig hjerte- og karsykdom hos menn med s-HDL-kolesterol > 1,0 mmol/l, uten blodtrykksbehandling eller 
kjent hjerte- og karsykdom i familien (3). Grønn farge betyr lav risiko, gul middels risiko og rød høy risiko.

Vi har beregnet samlet tiårsrisiko for dødelige og ikke-dødelige hjerteinfarkt og hjerneslag,

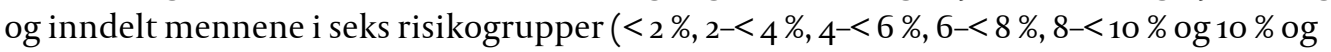
høyere) ut fra NORRISK-2-skår, og tatt med Helsedirektoratets tilleggsfaktorer i vurderingen av om intervensjon ville ha blitt anbefalt i dag.

\section{STATISTISKE ANALYSER}

Data fra basisundersøkelsen hos de overlevende og døde ble sammenliknet med t-test for kontinuerlige variabler og khikvadrattest for kategoriske variabler. Cox-regresjonsanalyser ble brukt for å teste forskjeller mellom høyeste og laveste kvartil med hensyn til risiko for kliniske endepunkter (for dagligrøyking: ja/nei). Relativ risiko ble utrykt som hasardratio med $95 \%$ konfidensintervaller. Følgende kovariater var med i modellen: alder, systolisk blodtrykk, dagligrøyking, kroppsmasseindeks, s-totalkolesterol, fysisk yteevne, s-K ${ }^{+}$og hvilepuls. Kovariatene, med unntak av alder og dagligrøyking, er inkludert som kvartiler, og vi viser hasardratio for høyeste mot laveste kvartil. Resultater med tosidig p-verdi < 0,05 ble ansett som signifikante. Kumulativ andel som opplevde et endepunkt, ble beregnet med Kaplan-Meier-kurver. Alle statistiske analyser ble utført med JMP 12 (SAS Institute Inc., Cary, NC, USA).

\section{Resultater}

Ti år etter basisundersøkelsen var 125 av de 2014 mennene døde (alle dødsårsaker, tabell 1). De tidlig døde var i snitt eldre (52,5 år), var i større grad dagligrøykere (66 \%), var i dårligere fysisk form og hadde høyere hvilepuls enn de overlevende. De hadde økt systolisk blodtrykk, $\varnothing \mathrm{kt}$ totalkolesterol og $ø \mathrm{kt}$ mengde triglyserider (alle $\mathrm{p}<0,05$, tabell 1).

\section{Tabell 1}

Funn ved basisundersøkelsen i Oslo Ischemia Study (med standarddeviasjoner) og sykdom/død innen ti år.

\begin{tabular}{|c|c|c|c|c|c|c|}
\hline Variabel & $\begin{array}{l}\text { I live } \\
(\mathrm{n}=1 \\
889)\end{array}$ & $\begin{array}{l}\text { Døde } \\
\text { (alle } \\
\text { årsaker })(\mathbf{n}= \\
\text { 125) }\end{array}$ & P-verdi & $\begin{array}{l}\text { Ikke } \\
\text { hjerte- og } \\
\text { karsykdom } \\
(n=1858)\end{array}$ & $\begin{array}{l}\text { Hjerte- og } \\
\text { karsykdom } \\
(n=156)\end{array}$ & P-verdi \\
\hline Alder (år) & $49,7(5,5)$ & $52,5(5,2)$ & $<0,001$ & $49,7(5,5)$ & $51,3(5,5)$ & $<0,001$ \\
\hline Dagligrøyker (n) & $\begin{array}{r}799 \\
(42 \%)\end{array}$ & $83(66 \%)$ & $<0,001$ & 793 (42 \%) & $89(57 \%)$ & $<0,001$ \\
\hline $\begin{array}{l}\text { Systolisk blodtrykk } \\
(\mathrm{mm} \mathrm{Hg})\end{array}$ & $\begin{array}{l}129,8 \\
(17,5)\end{array}$ & $134,9(21,8)$ & 0,01 & $130,0(17,9)$ & $131,5(17,3)$ & 0,30 \\
\hline $\begin{array}{l}\text { Diastolisk blodtrykk } \\
(\mathrm{mm} \mathrm{Hg})\end{array}$ & $\begin{array}{r}87,0 \\
(10,3)\end{array}$ & $88,7(11,8)$ & 0,12 & $87,0(10,4)$ & $87,5(10,6)$ & 0,64 \\
\hline Hvilepuls (slag/min) & $\begin{array}{r}61,3 \\
(10,0)\end{array}$ & $63,2(10,8)$ & 0,05 & $61,4(9,8)$ & $61,3(8,4)$ & 0,87 \\
\hline $\begin{array}{l}\text { Kroppsmasseindeks } \\
\left(\mathrm{kg} / \mathrm{m}^{2}\right)\end{array}$ & $24,5(2,7)$ & $25,0(3,1)$ & 0,15 & $24,5(2,7)$ & $24,9(3,0)$ & 0,18 \\
\hline $\begin{array}{l}\text { Fysisk yteevne } \\
(\mathrm{kJ} / \mathrm{kg})\end{array}$ & $\begin{array}{r}1,46 \\
(0,56)\end{array}$ & $1,09(0,47)$ & $<0,001$ & $1,45(0,56)$ & $1,20(0,45)$ & $<0,001$ \\
\hline $\begin{array}{l}\text { Totalkolesterol } \\
(\mathrm{mmol} / \mathrm{l})\end{array}$ & $6,6(1,2)$ & $7,0(1,2)$ & 0,001 & $6,6(1,2)$ & $7,0(1,2)$ & $<0,001$ \\
\hline
\end{tabular}




\begin{tabular}{|c|c|c|c|c|c|c|}
\hline Variabel & $\begin{array}{l}\text { I live } \\
(n=1 \\
889)\end{array}$ & $\begin{array}{l}\text { Døde } \\
\text { (alle } \\
\text { årsaker) }(\mathbf{n}= \\
\text { 125) }\end{array}$ & P-verdi & $\begin{array}{l}\text { Ikke } \\
\text { hjerte- og } \\
\text { karsylkdom } \\
(n=1858)\end{array}$ & $\begin{array}{l}\text { Hjerte- og } \\
\text { karsykdom } \\
(n=156)\end{array}$ & P-verdi \\
\hline $\begin{array}{l}\text { Triglyserider } \\
(\mathrm{mmol} / \mathrm{l})\end{array}$ & $1,3(0,7)$ & $1,5(0,7)$ & 0,01 & $1,31(0,7)$ & $1,43(0,8)$ & 0,056 \\
\hline
\end{tabular}

Kardiovaskulær sykdom debuterte hos 156, og 61 av dem døde. Risikofaktorene for kardiovaskulær sykdom og død var de samme som for total dødelighet, bortsett fra at systolisk blodtrykk ikke var statistisk signifikant sykdomsprediktor (tabell 1). I en multivariabel levetidsmodell var dagligrøyking, kolesterol og fysisk yteevne ved undersøkelsen signifikante prediktorer for tiårstotaldødelighet og kardiovaskulære hendelser (tabell 2).

\section{Tabell 2}

Hasardratio i multivariable levetidsmodeller med prediktorene alder, systolisk blodtrykk, dagligrøyking, kroppsmasseindeks, serum-totalkolesterol, fysisk form, serum-K+ og hvilepuls. Konfidensintervaller i parentes. Statistisk signifikante forskjeller (tosidig p-verdi $<0,05)$ er uthevet. $\mathrm{N}=2$ 014. Q4 vs. Q1 = risikoforhold mellom høyeste og laveste kvartil. S$\mathrm{K}+=$ kaliumkonsentrasjon i serum.

\begin{tabular}{|c|c|c|c|}
\hline Variabel & $\begin{array}{l}\text { Døde innen ti år } \\
(\mathbf{n}=125) \\
\text { Hasardratio }\end{array}$ & $\begin{array}{l}\text { Døde av hjerte- og } \\
\text { karsykdom innen ti år } \\
(\mathrm{n}=61) \\
\text { Hasardratio }\end{array}$ & $\begin{array}{l}\text { Syke eller døde av } \\
\text { hjerte- og } \\
\text { karsykdom innen ti } \\
\text { år }(n=156) \\
\text { Hasardratio }\end{array}$ \\
\hline $\begin{array}{l}\text { Alder } \\
\text { (Q4 vs Q1) }\end{array}$ & $1,64(0,92--3,06)$ & $1,16(0,54-2,71)$ & $1,35(0,81-2,29)$ \\
\hline $\begin{array}{l}\text { Systolisk blodtrykk } \\
\text { (Q4 vs. Q1) }\end{array}$ & $1,00(0,62-1,66)$ & $0,87(0,43-1,83)$ & $1,22(0,75-1,99)$ \\
\hline $\begin{array}{l}\text { Dagligrøyking } \\
\text { (Ja/Nei) }\end{array}$ & $2,22(1,53-3,27)$ & $1,54(0,92-2,63)$ & $1,46(1,06-2,03)$ \\
\hline $\begin{array}{l}\text { Kroppsmasseindeks } \\
\text { (Q4 vs. Q1) }\end{array}$ & $1,25(0,78-2,02)$ & $1,07(0,53-2,21)$ & $1,08(0,69-1,68)$ \\
\hline $\begin{array}{l}\text { S-kolesterol } \\
\text { (Q4 vs. Q1) }\end{array}$ & $1,80(1,08-3,09)$ & $2,95(1,34-7,42)$ & $2,04(1,27-3,35)$ \\
\hline $\begin{array}{l}\text { Fysisk form } \\
\text { (Q4 vs. Q1) }\end{array}$ & $0,45(0,23-0,84)$ & $0,31(0,11-0,77)$ & $0,33(0,19-0,58)$ \\
\hline $\begin{array}{l}\text { S-K } \\
\text { (Q4 vs. Q1) }\end{array}$ & $1,42(0,82-2,49)$ & $1,67(0,75-3,80)$ & $1,22(0,73-2,05)$ \\
\hline $\begin{array}{l}\text { Hvilepuls } \\
\text { (Q4 vs. Q1) }\end{array}$ & $1,63(0,96-2,87)$ & $1,43(0,67-3,19)$ & $0,93(0,57-1,52)$ \\
\hline
\end{tabular}


Figur 2 viser andelen kardiovaskulære hendelser (akutt hjerteinfarkt og hjerneslag) innen ti år, fordelt etter NORRISK-2-skår. Figuren viser en jevn risikoøkning med økende skår, opp til 12,6\% i høyeste klasse. Observert tiårsrisiko var gjennomgående litt høyere enn predikert risiko. Kaplan-Meier-kurver viser økende andel endepunkter fra lav til middels og høy beregnet risiko (figur za og 3b). Av 1128 deltakere i aldersgruppen 45-54 år og 416 i gruppen 55-6o år døde henholdsvis 25 og 27 av kardiovaskulær årsak. Dagens retningslinjer for intervensjon identifiserte henholdsvis 21 (84\%) og 22 (81\%) høyrisikopersoner blant disse.

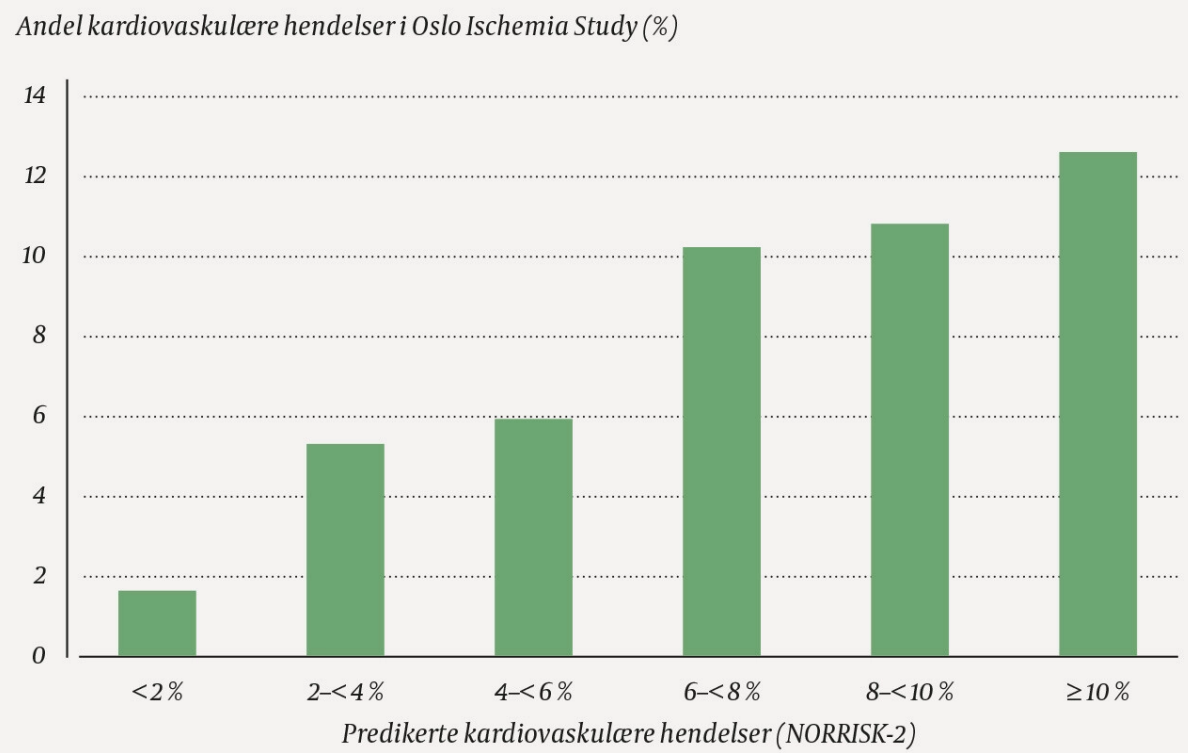

Figur 2 Observert andel deltakere i Oslo Ischemia Study som utviklet kardiovaskulære hendelser innen ti år, gruppert etter NORRISK-2-skår.
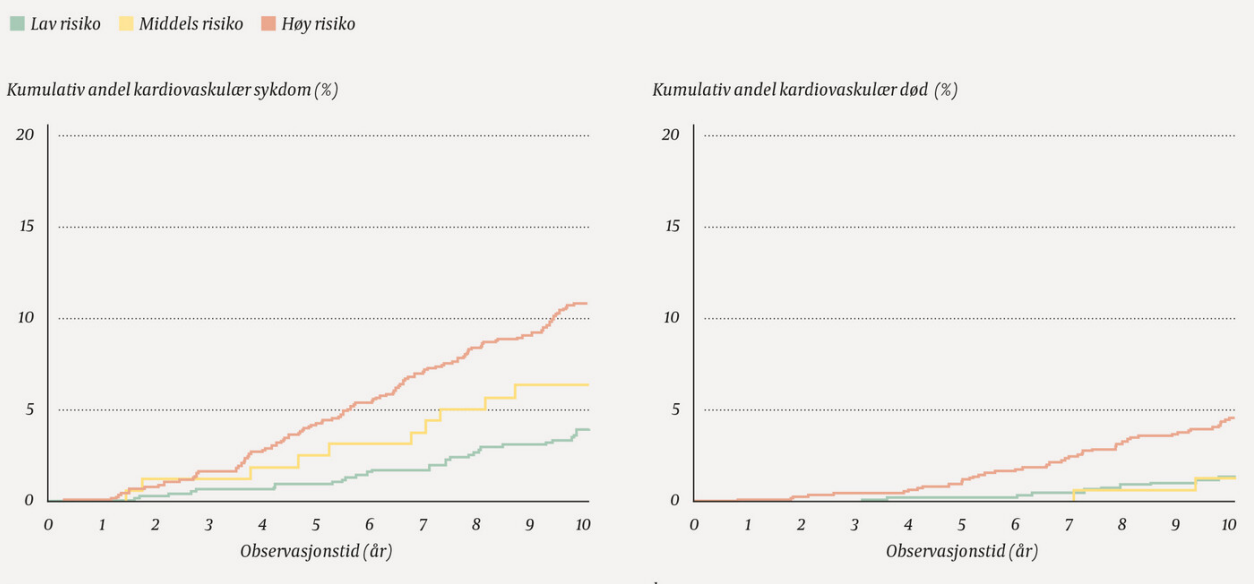

Figur 3 Kumulativ andel som fikk hjerteinfarkt eller hjerneslag, gruppert etter NORRISK-2skår med Helsedirektoratets tillegg. a) Kardiovaskulær sykdom (n=156). b) Kardiovaskulær $\mathrm{d} ø \mathrm{~d}(\mathrm{n}=61)$.

FYSISK YTEEVNE

Fysisk yteevne skilte de som utviklet kardiovaskulær sykdom, fra de fortsatt friske, også justert for NORRISK-2-skår: Sammenliknet med den minst fysisk aktive kvartilen har den mest aktive en hasardratio på o,33 (konfidensintervall o,19-0,58) for å utvikle hjerte- og karsykdom innen ti år (tabell 2). Figur 4 indikerer at stratifisering av NORRISK-gruppene etter fysisk yteevne over eller under medianen gir forskjeller i risiko mellom høy og lav fysisk yteevne for kombinert endepunkt hjerteinfarkt og hjerneslag i gruppene med lav og moderat høy risiko ( $<5 \%$ og 5-10 \%), mens dette ikke ser ut til å være tilfelle i høyeste risikogruppe. 


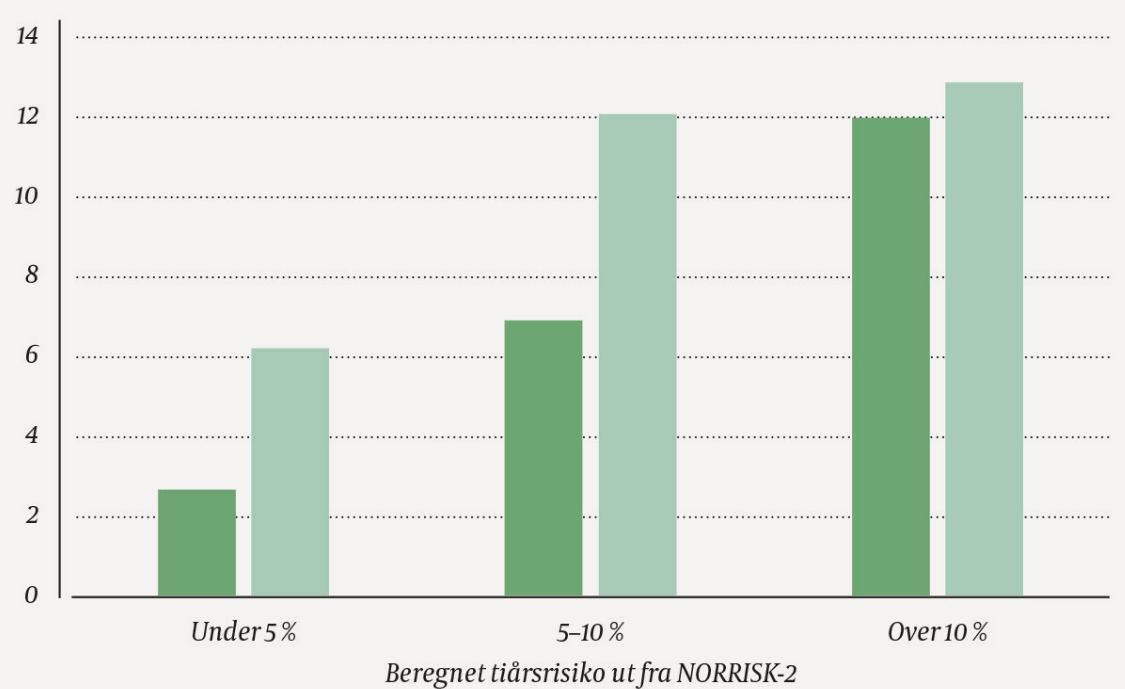

Figur 4 Andel kardiovaskulære hendelser i Oslo Ischemia Study innen ti år, fordelt på NORRISK-2-grupper oppdelt etter fysisk yteevne over eller under medianen.

\section{Diskusjon}

De som døde innen ti år, hadde overvekt av risikofaktorer: høyere alder, større andel dagligrøykere, høyere systolisk blodtrykk, høyere hvilepuls og høyere totalkolesterolverdi. De hadde også lavere fysisk yteevne. Dagens retningslinjer (NORRISK-2 med Helsedirektoratets tillegg) identifiserte godt de kardiovaskulære høyrisikoindividene i kohorten. Mange som ville ha blitt anbefalt intervensjon, klarte seg imidlertid gjennom de ti første årene uten kardiovaskulær sykdom eller død. Den lave spesifisiteten betyr imidlertid ikke at screening og forebyggende medisin ville ha vært uten gevinst: De fortsatte som høyrisikopopulasjon fremover, og et stort antall utviklet noe senere hjerte- og karsykdom, slik oppfølgingsdata fra Oslo Ischemia Study viser (므).

Det er interessant at NORRISK-2-modellen har god validitet i en studie fra 1970-årene, en tid med mindre blodtrykksbehandling og ennå ingen statiner. Blodtrykk som risikofaktor slår mye sterkere inn senere i studien (1ㅡ) sammenliknet med ti års observasjonstid her. Studien bekrefter at NORRISK-2 med Helsedirektoratets tilleggsfaktorer identifiserer de fleste norske middelaldrende menn som trenger forebyggende behandling mot kardiovaskulær sykdom.

Dårlig fysisk yteevne er assosiert med økt risiko for hjerte- og karsykdom (12,13). Dette vises også i våre resultater for de første ti år (tabell 1 og 2, figur 4). Vi har tidligere påvist at forbedret fysisk yteevne reduserer risikoen for hjerneslag (14).), atrieflimmer $(5,15)$ og muligens også kreft (트). Fysisk yteevne er dermed en påvirkelig risikofaktor som man kan diskutere om bør inngå i vurderingen av behovet for forebyggende behandling. NORRISK-2 omfatter bare faktorer som måles eller etterspørres hos allmennlegen, mens fysisk yteevne i vår studie er målt ved arbeids-EKG. De med høyest NORRISK-2 skår (rødt) blir uansett anbefalt medisinering, mens de med lavest skår (grønt) ikke blir det. Ut fra assosiasjonen mellom fysisk yteevne og tiårsresultat (figur 4) kunne man tenke seg at de med lav fysisk yteevne og middels risiko (gul gruppe) kunne bli anbefalt forebyggende behandling, mens de fysisk spreke kunne vurderes som de grønne. Gevinsten av en slik vurdering var ikke 
statistisk signifikant her, men det er likevel mulig at allmennlegens skjønnsmessige vurdering av fysisk form til over eller under medianen, vil kunne hjelpe i behandlingsvalget i tvilstilfeller der NORRISK-2-skår er i gul sone.

\section{STYRKE OG BEGRENSNINGER}

Oslo Ischemia Study er en prospektiv observasjonsstudie med lang oppfølgingstid og nær fullstendige data på alle deltakerne. Alle mennene var friske, uten medisinbruk og i full jobb ved inklusjonen. Sannsynligvis var det en enda større andel høyrisikopersoner blant de som ikke ble inkludert i studien, og det er sannsynlig at noen med høy risiko senere ble satt på forebyggende behandling. Begge disse forholdene tilsier at NORRISK-2-

prediksjonsevnen kan være enda større. Våre funn kan ikke direkte overføres til syke eller til kvinner. Våre 2014 deltakere bodde i Oslo, mens NORRISK-2 er basert på 51425 menn fra hele landet. Svært få, om noen, finnes i begge databasene.

Da Oslo Ischemia Study startet, var dagligrøyking vanligere enn nå (17), mens metabolsk syndrom og diabetes type 2 i dag er vanligere enn på den tiden. I Tromsøundersøkelsen har man vist at NORRISK-2-skårene for hvert alderstrinn er redusert gjennom årene (묘). Figur 2 viser dessuten at vår studiepopulasjon fra 1970-årene har noe høyere antall

kardiovaskulære hendelser enn man ville vente ut fra NORRISK-2-skårene, som er basert på data fra 20-25 år senere. Populasjonene blir dermed noe forskjellige. NORRISK-2 omfatter aldersgruppen 45-74 år, mens deltakerne i Oslo Ischemia Study var 40-59 år. Vi klassifiserte de yngste i lavrisikogruppen, men prinsipielt bør ikke NORRISK-2-kriteriene anvendes på dem.

\section{KLINISKE IMPLIKASJONER}

Helsescreening blant friske er omdiskutert på grunn av faren for overdiagnostikk og overmedisinering (19.). Verdens helseorganisasjon har definert kriterier for å evaluere populasjonsbaserte screeningstester. Kriteriene innebærer blant annet at screeningen skal være for sykdommer med alvorlige konsekvenser, hvor screening kan gi en potensiell fordel for dem det gjelder. Testen må være plausibel og ikke skadelig i seg selv, det må finnes en effektiv behandling for sykdommen hvis den oppdages i et tidlig stadium, og dessuten må det gis nøytral informasjon til befolkningen, slik at man selv skal kunne

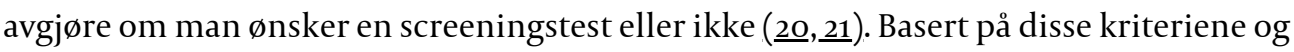
våre funn mener vi at NORRISK-2 med Helsedirektoratets tilleggsfaktorer kan anbefales som et praktisk instrument i den daglige utkikk etter personer med høy kardiovaskulær risiko.

I studien ble fysisk yteevne vurdert ved arbeidstest på ergometersykkel og funnet viktig for prognosen. I allmennpraksis kan man trygt oppfordre de fleste til økt fysisk aktivitet, og kanskje gjøre en skjønnsmessig vurdering av fysisk form og starte forebyggende behandling hos de som har moderat forhøyet NORRISK-2-skår (gul sone) og dårlig fysisk yteevne.

Vi må poengtere at NORRISK-2 bare er et verktøy for risikoskåring, og at høyrisikopersonene må få en sterkt motiverende og intens oppfølging.

KONKLUSJON

Forebygging av hjerte- og karsykdom hos høyrisikopersoner kan gi store helsegevinster, så det er viktig å finne ut hvem som har behov for preventive tiltak. Risikoprofilen til de tidlig døde middelaldrende mennene i Oslo Ischemia Study viser opphopning av klassiske risikofaktorer for hjerte- og karsykdom. Gjennom applikasjon av NORRISK-2 på deltakerne i Oslo Ischemia Study ser vi at modellen fanger opp høyrisikoindivider. Dette styrker bruken av denne enkle risikoskårmodellen i arbeidet med primærforebygging av hjerte- og karsykdom. 


\section{LITTERATUR}

1. Folkehelserapporten. Hjerte- og karsykdommer i Norge. https://www.fhi.no/nettpub/hin/ikkesmittsomme/Hjerte-kar/\#hovedpunkter Lest 27.12.2019.

2. Rossello X, Dorresteijn JA, Janssen A et al. Risk prediction tools in cardiovascular disease prevention: A report from the ESC Prevention of CVD Programme led by the European Association of Preventive Cardiology (EAPC) in collaboration with the Acute Cardiovascular Care Association (ACCA) and the Association of Cardiovascular Nursing and Allied Professions (ACNAP). Eur J Cardiovasc Nurs 2019; 18: 534-44. [PubMed][CrossRef]

3. Selmer R, Igland J, Ariansen I et al. NORRISK 2: A Norwegian risk model for acute cerebral stroke and myocardial infarction. Eur J Prev Cardiol 2017; 24: 773-82. [PubMed][CrossRef]

4. Erikssen J, Rasmussen K, Forfang K et al. Exercise ECG and case history in the diagnosis of latent coronary heart disease among presumably healthy middle-aged men. Eur J Cardiol 1977; 5: 463-76. [PubMed]

5. Grundvold I, Skretteberg PT, Liestøl K et al. Low heart rates predict incident atrial fibrillation in healthy middle-aged men. Circ Arrhythm Electrophysiol 2013; 6: 726-31. [PubMed][CrossRef]

6. Naess O, Søgaard AJ, Arnesen E et al. Cohort profile: cohort of Norway (CONOR). Int J Epidemiol 2008; 37: 481-5. [PubMed][CrossRef]

7. Sulo G, Igland J, Vollset SE et al. Cardiovascular disease and diabetes mellitus in Norway during 1994-2009: CVDNOR - a nationwide research project. Norwegian J Epidemiol 2013; 23: 101-7. [CrossRef]

8. Klemsdal TO, Gjelsvik B, Elling I et al. Nye retningslinjer for forebygging av hjerte- og karsykdom. Tidsskr Nor Legeforen 2017; 137. doi: 10.4045/tidsskr.17.0109. [PubMed][CrossRef]

9. Kalkulator for hjerterisiko. http://hjerterisiko.helsedirektoratet.no/ Lest 27.12.2019.

10. Heir T, Erikssen J, Sandvik L. Life style and longevity among initially healthy middle-aged men: prospective cohort study. BMC Public Health 2013; 13: 831. [PubMed][CrossRef]

11. Mundal R, Kjeldsen SE, Sandvik L et al. Exercise blood pressure predicts cardiovascular mortality in middle-aged men. Hypertension 1994; 24: 56-62. [PubMed][CrossRef]

12. Sandvik L, Erikssen J, Thaulow E et al. Physical fitness as a predictor of mortality among healthy, middle-aged Norwegian men. N Engl J Med 1993; 328: 533-7. [PubMed][CrossRef]

13. Engeseth K, Prestgaard EE, Mariampillai JE et al. Physical fitness is a modifiable predictor of early cardiovascular death: A 35-year follow-up study of 2014 healthy middle-aged men. Eur J Prev Cardiol 2018; 25: 1655-63. [PubMed][CrossRef]

14. Prestgaard E, Mariampillai J, Engeseth K et al. Change in cardiorespiratory fitness and risk of stroke and death. Stroke 2019; 50: 155-61. [PubMed][CrossRef]

15. Grundvold I, Skretteberg PT, Liestøl K et al. Importance of physical fitness on predictive effect of body mass index and weight gain on incident atrial fibrillation in healthy middle-age men. Am J Cardiol 2012; 110: 425-32. [PubMed][CrossRef]

16. Robsahm TE, Falk RS, Heir T et al. Cardiorespiratory fitness and risk of site-specific cancers: a longterm prospective cohort study. Cancer Med 2017; 6: 865-73. [PubMed][CrossRef]

17. Folkehelseinstituttet. Røyking og sosial ulikhet. https://www.fhi.no/nettpub/tobakkinorge/brukav-tobakk/royking-og-sosial-ulikhet/ Lest 27.12.2019.

18. Nilsen A, Hanssen TA, Lappegård KT et al. Secular and longitudinal trends in cardiovascular risk in a general population using a national risk model: The Troms $\emptyset$ Study. Eur J Prev Cardiol 2019; 26:185261. [PubMed][CrossRef]

19. IQWIG. Benefits and risks of screening tests. https://www.ncbi.nlm.nih.gov/books/NBK279418/ Lest 27.12.2019.

20. Wilson JMG, Jungner G. Principles and practice of screening for disease. Geneve: World Health Organization, 1968. https://apps.who.int/iris/handle/10665/37650 Lest 27.12.2019.

21. Petticrew MP, Sowden AJ, Lister-Sharp D et al. False-negative results in screening programmes: systematic review of impact and implications. Health Technol Assess 200o; 4: 1-120. [PubMed] [CrossRef]

Publisert: 7. september 2020. Tidsskr Nor Legeforen. DOI: 10.4045/tidsskr.20.0089 
Mottatt 1.2.2020, første revisjon innsendt 16.4.2020, godkjent 26.5.2020.

Publisert under åpen tilgang CC BY-ND. Lastet ned fra tidsskriftet.no 26. april 2023. 